\title{
Predicting decay and round-wood end use volume in trembling aspen (Populus tremuloides Michx.)
}

\author{
Robert SCHNEIDER ${ }^{1}$, Martin RIOPEL $^{2}$, David POTHIER ${ }^{2}$, Lévis CÔTÉ $^{3 *}$ \\ ${ }^{1}$ Département des sciences biologiques, Université du Québec à Montréal, c.p. 8888, succ. CV Montréal, Qc, Canada H3C 3P8 \\ ${ }^{2}$ Département des sciences du bois et de la forêt, Université Laval, Québec, Qc, Canada G1V 0A6 \\ ${ }^{3}$ Ministère des Ressources naturelles et de la Faune, Gouvernement du Québec, 92, $2^{e}$ rue ouest, bureau 207, Rimouski, Qc, Canada G5L 8B3
}

(Received 20 November 2007; accepted 5 May 2008)

\begin{abstract}
-
- In Quebec (Canada), predicting net merchantable volume of standing trees is essential to adjust stumpage fees. Furthermore, round-wood end use is important in the provincial forest management context because it is used to split the allowable annual cut among the different mill types.

- A method relying on linear, binomial and cumulative logit regressions is proposed to predict both decay volume and round-wood end use volume. Tree age, height and quality, as well as ecological region, stand origin and presence of Phellinus tremulae (Bond.) Bond. \& Boriss. and Ceratocystis fimbriata (Ellis \& Halst.) fungi are the main factors that contribute to the presence and the proportion of decayed merchantable volume. Once the net merchantable volume is estimated, its division into round-wood end use is estimated through a series of steps involving the presence of Phellinus tremulae, saw log height, stem quality and size as explanatory variables. The first step is a multinomial regression which predicts the number of end uses (pulp wood, low-grade saw logs, saw logs, low-grade veneer, and veneer) that are present in the stem. A series of logistic regressions then determines the presence of each end use, with linear regressions predicting the round-wood volume of each end use.
\end{abstract}

forest products / forest management / decay / modelling / trembling aspen

Résumé - Prévision du volume de bois carié et de la répartition par produits chez le peuplier faux-tremble (Populus tremuloides Michx.).

- Au Québec (Canada), la prévision du volume marchand net des arbres sur pied est indispensable pour déterminer les droits de coupe. En outre, la répartition par produits du volume marchand net est essentielle dans le contexte de la gestion forestière régionale car c'est cette étape qui détermine la portion de la possibilité forestière qui est attribuée aux différentes usines de transformation.

- Une méthode utilisant des régressions linéaires, binomiales et logistiques cumulatives est proposée pour prédire à la fois le volume de carie et sa répartition par produits. L'âge de l'arbre, la hauteur et la qualité, comme la région écologique, l'origine du peuplement et la présence de champignons Phellinus tremulae (Bond.) Bond. \& Boriss. et Ceratocystis fimbriata (Ellis \& Halst.) sont les principaux facteurs qui contribuent à la présence et à la proportion du volume de bois carié. Une fois le volume marchand net estimé, sa répartition par produits est estimée à travers une série d'étapes impliquant la présence de Phellinus tremulae, la hauteur de bois d'oeuvre, la qualité et la taille des tiges comme variables explicatives. La première étape est une régression logistique cumulative qui prédit le nombre d'utilisations finales (bois de pâte, sciage de basse qualité, bille de sciage, placage de basse qualité et placage) qui sont présentes dans le tronc. Une série de régressions logistiques détermine alors la présence de chacune de ces utilisations. Enfin, des régressions linéaires prédisent le volume marchand net de chaque utilisation.

produits forestiers / gestion forestière / pourriture / modélisation / Populus tremuloüdes Michx.

\section{INTRODUCTION}

The allowable annual cut (AAC) in the Province of Quebec is calculated every five years as part of the general management plan. The allowable annual cut is defined as the maximum annual merchantable volume that can be sustainably harvested (Quebec Provincial Government, 2007). One of the important variables used to calculate the allowable annual cut is the standing volume of the forest. This is estimated for each forest stratum, i.e. the distinct layers of vegetation within a forest community (Ordre des ingénieurs forestiers du Québec, 2003), with survey data combined with a two entry standard merchantable volume table: diameter at breast height and total

* Corresponding author: robert.schneider.1@ulaval.ca height (Perron, 1985). The AAC is calculated in terms of gross merchantable volume, whereas stumpage fees and wood actually processed by forest product mills is calculated with the net merchantable volume. Several studies have already shown that the prediction of the net merchantable volume needs to be studied further (Blouin et al. 2001; Patry, 2004).

Trembling aspen (Populus tremuloides Michx.) is one of the species most affected by decay in Canada. Hence, under certain conditions, net volume can decrease markedly and thus contribute to the underutilization of this species (Basham, 1991). A better understanding of decay and the factors that influence its presence and its importance would improve our capacity to produce higher quality trembling aspen for the forest industry. Tools are thus needed to help foresters identify trees that have decay and to estimate the subsequent loss in 
merchantable volume (Hiratsuka and Loman, 1984). Basham (1991) states that it is easy to evaluate these indicators by a visual inspection of a standing stem. Phellinus tremulae (Bond.) Bond. \& Boriss., which is identified by the horseshoe conk it forms, produces white trunk rot (Hiratsuka and Loman, 1984). Other pathogens can cause, or at the very least create, an entry point for wood degrading fungi. One of these is the hypoxylon canker (Hypoxylon mammatum (Wahl.) J. Mill.) that is responsible for sapwood rot, which in turn increases the risk of stem breakage at this point (Anderson, 1964). Armillaria sp. is generally responsible for yellow stringy decay in the root system and its presence can be determined by observing mycelial fans between the bark and the wood (Lachance, 1984). Ceratocystis fimbriata (Ellis \& Halst.) is identified by target cankers on the stem which create an open wound (Myren et al., 1994). This wound becomes an entry point for other fungi which can affect the heartwood and decrease the number of saw logs in the stem. Moreover, the presence of this canker in combination with wind could cause tree mortality (Walters et al., 1982).

Before the 1980's, numerous studies in North America analyzed the amount of decay in trembling aspen through age class averages (Basham, 1958; Basham and Morawski, 1964; Hinds and Wengert, 1977; Morawski et al., 1958; Paul and Etheridge, 1958; Riley, 1952). However, these studies did not attempt to model the probability of finding decay in a stem nor its volume. During the last decade, logistic regressions were used to model rot probability functions in Europe (Knoke, 2003; Thor et al., 2005). In Western Canada, LeMay et al. (1994) used classification-tree analysis to distinguish decayed versus sound trembling aspen. They also estimated percent decay from tree characteristics (LeMay et al., 1993). In Eastern Canada, such models would be needed to evaluate decay volume at the stand level using forest survey data.

The allowable annual cut is allocated to the different mills having logging rights on the public land by the use of arithmetic means calculated from felled trees randomly selected across the province, regardless of site or regional variables. The underlying assumption of the method is that a tree of known diameter at breast height (dbh) and quality class produces a fixed proportion of a given product, irrespective of the region from which it comes. As with the net volume predictions, bias in the proportion of a given product can be produced by applying these general characteristics to a specific region (Blouin et al., 2001).

Models for predicting round log and tree quality have been developed using complex approaches, usually including linear discriminant analysis (Belli et al., 1993; Hilpp and Pelkki, 2003; Morris and Parker, 1992; Yaussy et al., 1988). This type of analysis is used to classify an observation into a group using a linear combination of dependant variables. However, if the quantitative variables are not normally distributed, or if an independent categorical variable is used in the analysis, the discriminant analysis might not be the best alternative (Press and Wilson, 1978). A cumulative logit model, which is a generalization of the binomial regression and can have independent categorical variables, is better suited to this kind of data. It consists of a regression where the cumulative probability is modeled using the same link functions as in the binomial case.
A full description of the statistical application of the cumulative logit model in forestry can be found in Prestemon (1998) where tree grade was predicted from stand and tree variables.

The first objective of this paper is to better understand the way external observations (i.e. presence of fungi, tree quality class) can be related to the net merchantable volume. The second objective is to propose a reliable method of dividing the net merchantable volume into different products.

\section{DATABASE}

Data were collected in mature unmanaged even-aged stands dominated by trembling aspen in the Bas-Saint-Laurent and Gaspésie regions of the province of Quebec, in Eastern Canada. Study stands were selected throughout the balsam fir/yellow birch and balsam fir/white birch bioclimatic domains of these regions. They are located on till or weathered deposits. The length of the growing seasons varies from 140 to 170 days with an average temperature ranging between 0 and $2.5^{\circ} \mathrm{C}$ (Robitaille and Saucier, 1998). According to the current provincial ecological classification (Saucier et al., 1998), five ecological regions were covered by the sampling: "Collines des moyennes Appalaches" (4f), "Côte gaspésienne" (4h), "Côte de la Baie des Chaleurs" (4g), "Massif gaspésien" (5h) and "Haut massif gaspésien" (5i). The stems felled in this study came from 109 temporary plots $\left(400 \mathrm{~m}^{2}\right)$ with age varying from 40 to 120 years.

In the sample plots, diameter at breast height (dbh), stem quality, and presence of fungi sporophores were determined for all merchantable trees (outside bark dbh larger than $9.0 \mathrm{~cm}$ ). Stem quality was evaluated following the survey instructions presently used in the province of Quebec (Perron and Morin, 2001). This four-class classification ('A', 'B', 'C', and ' $D$ ') is based on an evaluation of defects within the first $5 \mathrm{~m}$ above the stump, with ' $\mathrm{A}$ ' and ' $\mathrm{D}$ ' being the best and the worst classes, respectively. The minimum diameter at breast height (dbh) used to classify a stem in the ' $C$ ' and ' $D$ ' classes was $9.1 \mathrm{~cm}$, whereas the minimum dbh was $27.1 \mathrm{~cm}$ for classes ' $A$ ' and 'B'. In each plot, 10 trees were then randomly selected by respecting the proportion of tree quality classes, as described in detail in Pothier et al. (2004). On the sample trees, tree quality, dbh and presence of external indicator of fungi (Armillaria ostoyae, Ceratocystis fimbriata, Hypoxylon mammatum, Phellinus tremulae) were noted.

All the selected trees were then felled and stem diameter as well as decay diameter were measured $( \pm 1 \mathrm{~mm})$ at every metre until an inside bark diameter of $9.0 \mathrm{~cm}$ was reached (merchantable limit). As explained in the provincial scaling instructions (Ministère des Ressources naturelles, 2001), the rotten zone was visually evaluated and defined as severely degraded wood where the fibre structure has softened or is totally disintegrated, and which cannot be used in any wood products. The definition used in this study corresponds to levels III and IV defined by Zycha (1962) and used by Seifert (2007). Moreover, according to the provincial scaling rules (Ministère des Ressources naturelles, 2001), decay diameter is calculated as 
Table I. Stem characteristics of felled trees by ecological region (standard deviation in parentheses).

\begin{tabular}{lcccccc}
\hline Ecological region & No. of trees & $\begin{array}{c}\text { Dbh } \\
(\mathrm{cm})\end{array}$ & $\begin{array}{c}\text { Height } \\
(\mathrm{m})\end{array}$ & Age at 1 m above ground & $\begin{array}{c}\text { Merchantable volume } \\
\left(\mathrm{dm}^{3}\right)\end{array}$ & $\begin{array}{c}\text { Net merchantable volume } \\
\left(\mathrm{dm}^{3}\right)\end{array}$ \\
\hline $4 \mathrm{f}$ & 589 & $27.3(7.1)$ & $21.4(2.7)$ & $69(18)$ & $536(320)$ & $499(307)$ \\
$4 \mathrm{~g}$ & 100 & $28.0(7.9)$ & $19.8(3.3)$ & $67(18)$ & $533(354)$ & $514(339)$ \\
$4 \mathrm{~h}$ & 209 & $28.6(7.7)$ & $21.2(3.0)$ & $50(10)$ & $594(390)$ & $586(387)$ \\
$5 \mathrm{~h}$ & 159 & $26.5(6.4)$ & $20.8(2.5)$ & $54(13)$ & $491(275)$ & $370(128)$ \\
$5 \mathrm{i}$ & 29 & $26.4(4.1)$ & $17.9(1.2)$ & $545(272)$ & $363(129)$ \\
\hline
\end{tabular}

Table II. Log end-use definition as a function of small and large end diameter, minimum log length and maximum decay diameter.

\begin{tabular}{lccccc}
\hline Log quality & Log end-use & $\begin{array}{c}\text { Small end diameter } \\
(\mathrm{cm})\end{array}$ & $\begin{array}{c}\text { Max. large end diameter } \\
(\mathrm{cm})\end{array}$ & $\begin{array}{c}\text { Min. log length } \\
(\mathrm{cm})\end{array}$ & $\begin{array}{c}\text { Maximum decay diameter } \\
(\mathrm{cm})\end{array}$ \\
\hline A & Veneer & 27.1 & 79.1 & 250 & 250 \\
B & Low-grade veneer & 27.1 & & 250 & 4 \\
B & Saw log & 27.1 & & 250 & 6 \\
C & Saw log & 19.1 & & 250 \\
C & Low-grade saw log & 15.1 & 55.1 & & \\
D & Pulp wood & 9.1 & & \\
\hline
\end{tabular}

the diameter of a circle having the same area as that of the observed decay area. Total height was also measured. Tree age was determined at a height of $1 \mathrm{~m}$ above ground according to the reference age in the provincial yield tables (Pothier and Savard, 1998). Table I presents the mean tree characteristics. A random sub-selection of 5 trees from the 10 selected trees for the decay study was also made to separate the merchantable volume into end-use volume. These stems were bucked into $2.5 \mathrm{~m} \mathrm{logs}$, and $\log$ and decay diameters at each end were measured. Each log was graded for quality (Ministère des Ressources naturelles, 2001) and this was used together with small end diameter to determine log end-use (Tab. II). Total and decay volumes were calculated for the $1 \mathrm{~m}$ and $2.5 \mathrm{~m} \operatorname{logs}$ using Smalian's formula as described in the scaling instructions for the province (Ministère des Ressources naturelles, 2001). A total of 1086 trembling aspen stems were used for the decay modeling and 531 stems for the end-use volume modeling.

\section{METHODS}

\subsection{Determination of decay volume}

The flowchart illustrating the breakdown of the merchantable volume is shown in Figure 1. The determination of decay volume is the first step to obtain the net volume. For a better understanding of the data structure, let $i, j$, and $k$ define the plot, the tree and the product indices, respectively.

First, a generalized linear mixed model was used to predict the presence of decay in the stem. This model uses a link function, which transforms the probabilities in a linear function of explanatory variables over an interval $[-\infty,+\infty]$ (Collet, 2003). The logit link function can then be transformed into a probability.

$$
P r_{i j}=\frac{\mathrm{e}^{\text {LOGIT }_{\text {rot }, i j}}}{1+\mathrm{e}^{\text {LOGIT }_{r o t}, i j}}
$$

where $P r_{i j}$ is the probability of observing decay for tree $j$ in plot $i$ and LOGIT $_{r o t, i j}$ is the combination of linear predictors associated with the same tree and plot.

In this study, the regression was calibrated with the GLIMMIX macro in the SAS software, version 8.2 (SAS Institute Inc., 2006). This macro enables the use of a mixed procedure to compute a logistical regression in order to take into account the correlation between the stems sampled within the same plot with random variable $\left(u_{i}\right)$.

Significant variables of the model were determined with a stepwise method using the LOGISTIC procedure in the SAS statistical software prior to final calibration in the mixed regression (GLIMMIX macro). Variables submitted to the model include tree age at $1 \mathrm{~m}$ above ground $\left(a g e_{i j}\right)$, total tree height ( $h t_{i j}$ in $\left.\mathrm{m}\right)$, stand origin (fire or clearcut), presence or absence of external indicators of fungi, ecological region, dbh, stem quality, and ecological type. Tree height and tree age were poorly correlated because the felled stems were sampled in mature stands, within which height increment is very limited. Moreover, correlation between all of the parameters was verified. Variables were included in the mixed regression model when their parameter estimates were significantly $(p<0.05)$ different from zero.

The results suggest that ecological regions $\left(\mathrm{reg}_{i}\right)$ could be grouped into two homogeneous groups: 4f-4h: Collines des moyennes Appalaches (4f) and Côte gaspésienne (4h) $\left(r^{2} g_{i}=1\right)$; 4g-5h-5i: Côte de la Baie des Chaleurs (4g), Massif gaspésien (5h) and Haut massif gaspésien $(5 \mathrm{i})\left(\mathrm{reg}_{i}=0\right)$. Tree qualities 'A' and 'B' were also grouped together. The presence of Ceratocystis fimbriata and Phellinus tremulae were grouped into one dummy variable $\left(P T C F_{i j}\right)$. Furthermore, all trees older than 60 years that bore sporophores of either Ceratocystis fimbriata or Phellinus tremulae sporophores were observed to have decay (127 trees) as previously noted by Riley and Bier (1936). According to Allison (1999), logistic models should be elaborated without such data as to avoid a complete separation of data. Consequently, for trees bearing sporophores of these fungi, a logistic model was calibrated only for stems younger than 60 years. Ecological region, presence of Ceratocystis fimbriata and Phellinus tremulae, total height and age were found to be the only significant variables. The 


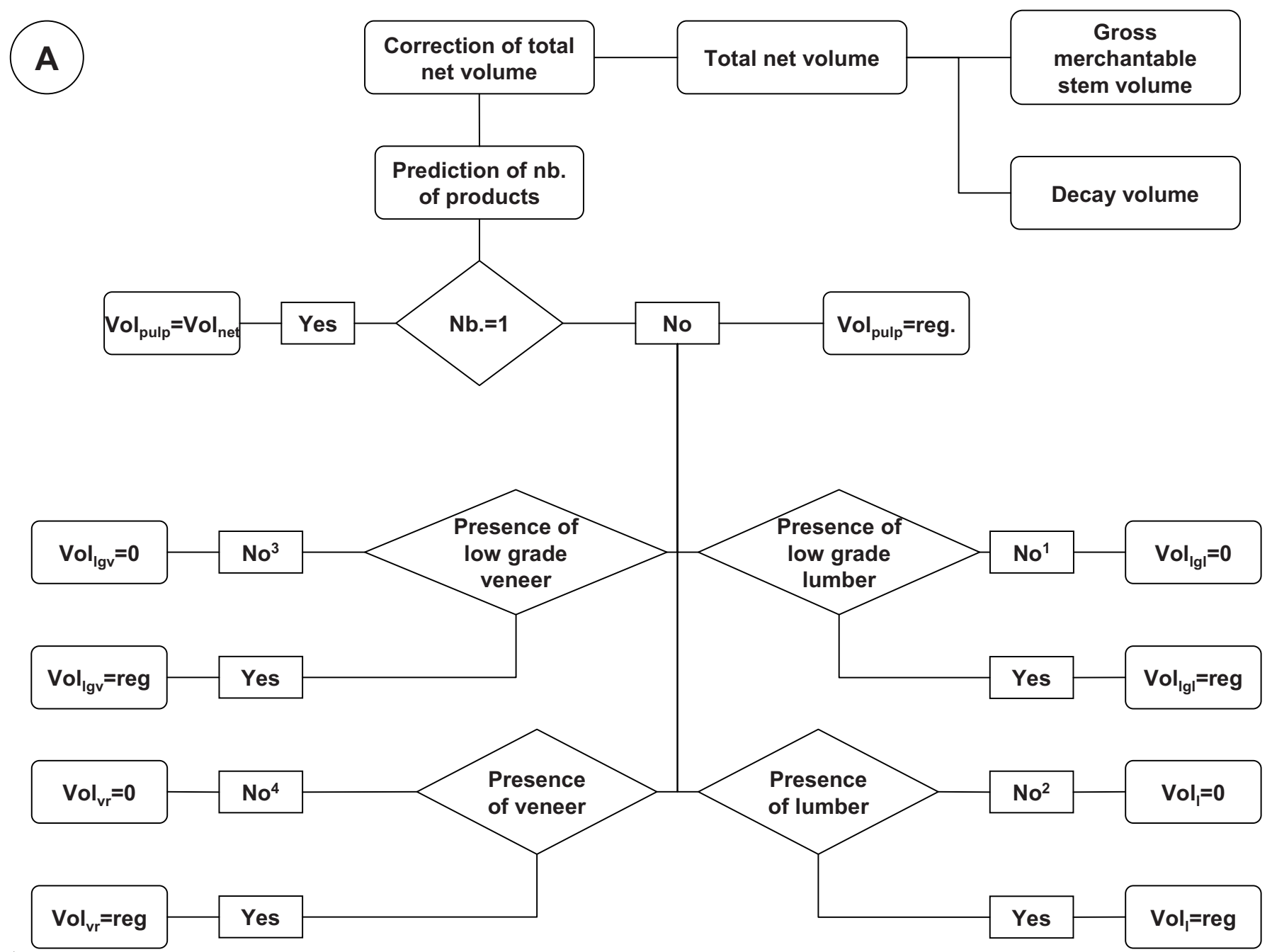

${ }^{1}$ If dbh less than $15.1 \mathrm{~cm}$, then the answer is automatically no.

${ }^{2}$ If dbh less than $19.1 \mathrm{~cm}$, then the answer is automatically no.

${ }^{3}$ If dbh less than $27.1 \mathrm{~cm}$ or the saw $\log$ height is less than $7 \mathrm{~m}$, then the answer is automatically no.

${ }^{4}$ If dbh less than $27.1 \mathrm{~cm}$ or the saw $\log$ height is less than $9 \mathrm{~m}$, then the answer is automatically no.
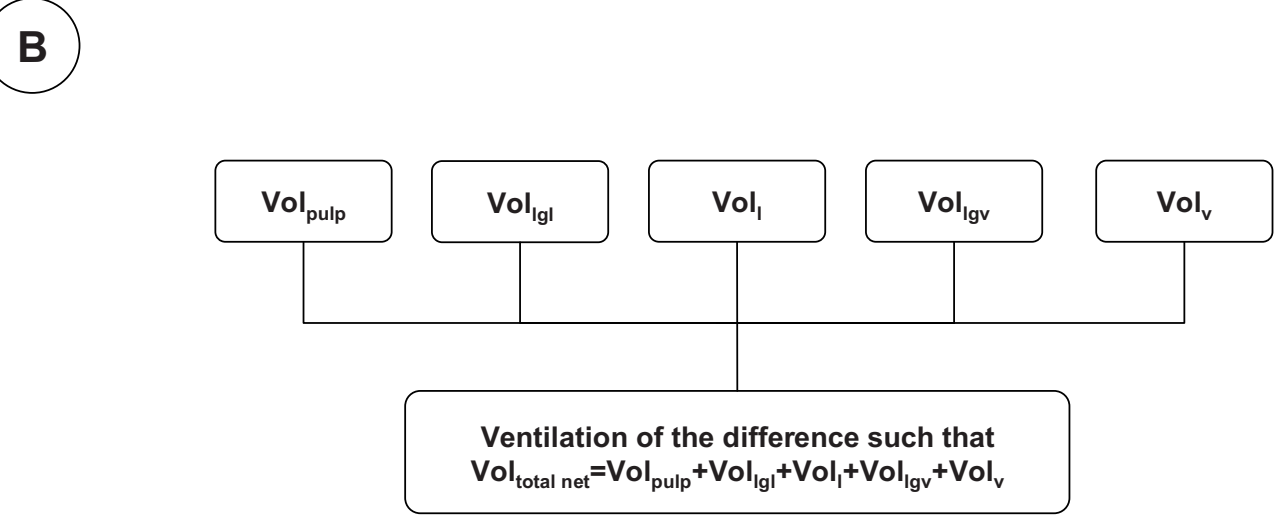

Figure 1. Flow chart illustrating the steps followed to breakdown the net merchantable volume into end-use volume (A: Steps to calculate end-use volume; B: Step to ensure that the sum of the end-use volume equals the total stem volume). 
final model could be expressed as follows:

$$
\operatorname{LOGIT}_{r o t, i j}=b_{0}+b_{1} \cdot a g e_{i j}+b_{2} \cdot h t_{i j}+b_{3} \cdot \operatorname{reg}_{i}+b_{4} \cdot P T C F_{i j}+u_{i}
$$

Equation (2) was then introduced into Equation (1) to calculate the probability of a tree being affected by decay.

To determine the volume of rot in a stem that was predicted to have decay, the logarithmic value of the proportion of stem volume affected by decay (decay volume to total merchantable volume ratio) was modeled using a linear mixed model (Eq. (3)). A mixed regression including the plots as a random variable $\left(u_{i}\right)$ was calibrated using the MIXED procedure of the SAS system to take into account the correlation of the trees sampled within the same plots (Littell et al., 1996).

$\log _{10}\left(\frac{\text { vol }_{\text {rot }, i j}}{\text { vol }_{\text {merch }, i j}}\right)=b_{0}+b_{1} \cdot a g e_{i j}+b_{2} \cdot h t_{i j}+b_{3} \cdot \operatorname{reg}_{i}+b_{5} \cdot$ fire $_{i}+b_{6, m}+u_{i}$

where $m$ is the quality class index such that $m=(\mathrm{A}, \mathrm{B}, \mathrm{C}, \mathrm{D})$. As to simplify the model, quality classes were merged together when the differences between them were non significant.

The advantages of using the logarithmic transformation are twofold: the observed heteroscedasticity is eliminated and the predicted ratio is always positive. To correct for bias generally associated with conversion from logarithmic to arithmetic units, Duan's nonparametric correction method was applied (Duan, 1983). This method, also referred to as a smearing estimate, consists in calculating the average values of the back transformed residuals. The correction factor (cor) is then applied as follows:

$$
Y=10^{Y^{\prime}} \cdot \operatorname{cor}
$$

The model was first calibrated with all the stems affected by decay, but produced an overestimation of the proportion for stems characterized by the presence of Phellinus tremulae sporophores, even when the presence was entered as a dummy variable. Hence, we performed two calibrations, one for the group of trees without Phellinus tremulae and the other for the trees bearing sporophores of this fungus.

The mathematical expectation of decay volume for a given stem can be calculated by joining the probability of observing decay (Eq. (1)) and the mean predicted proportion of decay volume given that decay is observed (Eq. (4)). For example, a stem with a $20 \%$ probability of having $25 \%$ proportion decay volume will have, on average, $5 \%$ decay.

\subsection{Net merchantable volume breakdown}

The second step in determining the net merchantable volume of each product is a scaling issue. Because a difference in total net merchantable volume is observed between scaling using $1 \mathrm{~m}$ (decay volume study) and $2.5 \mathrm{~m} \operatorname{logs}$ (volume breakdown), the stem volume has to be corrected $\left(\mathrm{Eq} .(5), \mathrm{R}^{2}=0.99, \mathrm{RMSE}=34 \mathrm{dm}^{3}\right)$. The MIXED procedure was used to calibrate the model with the plots as random effect.

$$
\operatorname{vol}_{\text {net }, 2.5 m, i j}=17.091+1.014 \cdot \text { volume }_{n e t, 1 m, i j}
$$

The third step models the number of products in the tree with a cumulative logit model using the GENMOD procedure in the SAS software. The cumulative logit of each category was modelled, from the lowest to the highest number of products (Allison, 1999). The regression yields $n-1$ equations, where $n$ is the number of possible categories. In this case, four levels where observed: the presence of one (i.e. pulp only), two (i.e. pulp and low grade sawlog; pulp and sawlog; pulp and low grade veneer; pulp and veneer), three (i.e. pulp, low grade sawlog; pulp, low grade sawlog and veneer; etc.), or four (i.e. pulp, low grade sawlog, sawlog and low grade veneer, etc) products in a stem (no stem had five products). For this regression, let $p$ be the index for the number of products within a particular stem, such that $p=(1,2,3)$. The cumulative logit of the model could be expressed as follows:

$C U M L O G I T_{i j}=b_{0, p}+b_{1, m}+b_{2} \cdot \operatorname{vol}_{n e t, 2.5 m, i j}+b_{3} \cdot a g e_{i j}+b_{4} \cdot h s_{i j}+b_{5} \cdot p t_{i j}$

where $v o l_{\text {net }, i j}$ is the total net volume on a $2.5 \mathrm{~m}$ scale for tree $j$ in plot $i\left(\mathrm{dm}^{3}\right), a g e_{i j}$ is the stem age, $h s_{i j}$ is the saw log height, height at which stem diameter reaches an inner bark diameter of $19.1 \mathrm{~cm}$ along the main stem (in m), and $p t_{i j}$ is the presence of Phellinus tremulae conks.

The cumlogit can be changed into probabilities similar to the logit link function in binomial regressions (Allison, 1999). The probability of having one product is simply the probability of the cumulative logit with $p=1$. The probability of having 2 or 3 products is given by the change into probability of the cumulative logit of 2 or 3 products from which is subtracted the sum of the probabilities of the lower number of products. Finally, the probability of having 4 products is simply one minus the sum of the probabilities of all the other number of products. The equations used to calculate the probability are as follows:

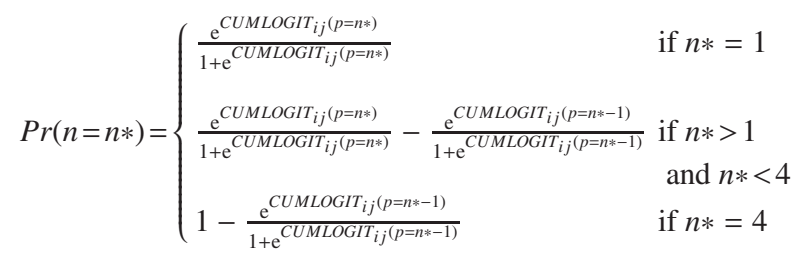

We used the model in a deterministic fashion. The number of products in the tree was determined by the highest predicted probability. This however does not give any direct information on the nature of the products present.

The tree is composed entirely of pulpwood when the predicted number of products equals one $\left(\mathrm{nb}_{i j}=1\right)$. However, the cumulative logit model does not give any information on the products which are found in the stem when the number of products is greater than 1 . The next step is to predict the presence of a given product $k$ (low-grade saw log, saw log, low-grade veneer, veneer) if the number of products in the stem is greater than $1\left(\mathrm{nb}_{i j}>1\right)$. This was done through a binomial mixed effect regression using the logit link function (Eq. (8)). The number of products for the following steps was not used as a limit, but more as a gauge for the following regressions (covariable), i.e. a tree with three products is not limited to this number. Preliminary trials indicated that when the predicted number of products was used as a limit, the model yielded an overestimation of the low end products and an underestimation of the higher end products. The models were calibrated using the GLIMMIX.SAS macro in the SAS software to be able to include the plots as random effect $\left(\mathrm{u}_{i}\right)$. The logit was changed into a probability as described earlier (Eq. (1)).

$$
\operatorname{LOGIT}_{i j k}=b_{k, 0}+b_{k, m}+b_{k, 4} \cdot h s_{i j}+b_{k, 6} \cdot n b_{i j}+b_{k, 7} \cdot d b h_{i j}+u_{i}
$$

The cutpoint, defined as the probability above which the presence of the product is predicted and below which the absence of the product is predicted, is determined by maximizing the sensibility and specificity 
of the models (SAS Institute Inc., 2002). The sensibility of a binomial regression is defined as the capacity to correctly predict the presence of the product, and the specificity as the capacity to correctly predict the absence of the product. As a starting point, the cutpoint is given as the number of stems with the given product divided by the total number of stems. The cutpoint is then varied by a correction factor as to maximize the sensibility and specificity of the model (Eq. (9)).

$$
\text { cutpoint }_{k}=\text { fact }_{\text {cor }}+\left[\frac{\text { number of stems with product } k}{\text { total number of stems }}\right]
$$

The last part of the system aims at calculating the volume of a given product when the presence of this product is predicted. The volume for each product $k$ was modeled through a mixed-effect model with the plot entered as a random effect (Eq. (10)). The logarithmic transformation was also used to eliminate the observed heteroscedasticity as well as to ensure that the predicted volume is always positive. The delogged value of the volume for a given product is calculated as described in Equation (4), using the same method in calculating the correction factor (Duan, 1983).

$$
\begin{gathered}
\log \left(\operatorname{vol}_{i j k}\right)=b_{k, 0}+b_{k, x}+b_{k, 2} \cdot v \operatorname{vol}_{n e t, 2.5 m, i j}+b_{k, 21} \cdot v o l_{n e t, 2.5 m, i j}^{2} \\
+b_{k, 4} \cdot h s_{i j}+b_{k, 6} \cdot n b_{i j}+b_{k, 7} \cdot d b h_{i j}+u_{i}
\end{gathered}
$$

The final step ensures that the sum of all the products equals the total net volume of the stem. The difference between the sum and the total is distributed according to the weight in volume of each product (Eq. (11)). This assumes that each product contributes to the difference between the predicted total merchantable volume of the stem and the sum of the volumes for each product, and that the contribution of each product is proportional to its predicted product volume.

$$
\operatorname{vol}_{\text {corrected }, i j k}=\operatorname{vol}_{i j k}+\left[\left(\operatorname{vol}_{n e t, 2.5 m, i j}-\sum_{k} \operatorname{vol}_{i j k}\right) \cdot \frac{\operatorname{vol}_{i j k}}{\operatorname{vol}_{n e t, 2.5 m, i j k}}\right]
$$

The model was cross-validated using a 10 fold cross-validation to assess its prediction error (Good, 2001). This cross-validation consists of randomly separating the data into 10 different groups. The models are then calibrated using 9 of the groups and validated with the 10th. This is done with each of the groups. The predicted height (not presented), saw log height (not presented), and net merchantable volume of each stem were used instead of the observed values, to give an idea of the overall observed variation.

The prediction sum of squares (PRESS) statistic, the root mean squared error of the prediction (RMSEP), and bias can then be calculated (Eqs. (12) to (14)). The PRESS statistic corresponds to the sum of the square root of the difference between the observed and predicted values (Vanclay, 1994).

$$
\begin{aligned}
\text { PRESS } & =\sum\left(\text { vol }_{\text {predicted }}-\text { vol }_{\text {observed }}\right)^{2} \\
R M S E P & =\sqrt{\frac{\sum\left(\text { vol }_{\text {predicted }}-\text { vol }_{\text {observed }}\right)^{2}}{n}} \\
\text { BIAS } & =\frac{\sum\left(\text { vol }_{\text {predicted }}-\text { vol }_{\text {observed }}\right)}{n}
\end{aligned}
$$

\section{RESULTS}

\subsection{Determination of decay volume}

The logistical regression indicates that the probability of observing decay in the stem is related to tree height, tree age, the ecological region and presence of Ceratocystis fimbriata and/or Phellinus tremulae sporophores (Tab. III). The predicted probabilities decrease with increasing height. The effect of height is more important for younger trees when compared to older ones (100 years old) where probabilities are higher than $90 \%$ (Fig. 2). Also, trees which are younger at given height have lower chances of having rot. The ecological regions also influence the probability of observing decay, with the $4 \mathrm{f}$ and $4 \mathrm{~h}$ regions, which are mostly located in the BasSaint-Laurent region, showing the highest probabilities. The probability of observing decay in trees increases when Ceratocystis fimbriata and/or Phellinus tremulae sporophores are present. For a 50 year old tree of $20 \mathrm{~m}$, the predicted probability increases from 55 to $80 \%$ in $4 \mathrm{~g}-5 \mathrm{~h}-5 \mathrm{i}$ regions when one of the two fungi are present (Fig. 2b). Moreover, all the stems aged over 60 years with sporophores had decay.

The statistics related to the models (RMSE) that predict the logarithmic transformation of the proportion of decay volume indicate large variations in the data (Tab. III). For stems without Phellinus tremulae sporophores, the effects of tree age, ecological region and total tree height on decay volume are similar to those related to the model of probability of observing rot (Fig. 3). The proportion of decay increases with increasing age and decreasing height (Tab. III). Furthermore, the amount of decay in the $4 \mathrm{f}$ and $4 \mathrm{~h}$ ecological regions is approximately twice as much as that observed for a similar tree in the $4 \mathrm{~g}$, 5h and $5 \mathrm{i}$ ecological regions. Moreover, a tree established after clear-cutting has less decay than a tree of fireorigin (Tab. III). The model logically predicts that stems of lower quality have a greater proportion of decayed wood (Fig. 3 ). Tree quality is a good indicator for decay volume within the stem, where the trees graded D (i.e. stems with the most defects) had the most decay volume. The differences between the trees classed A and B were statistically non significant and hence grouped together.

For stems with Phellinus tremulae sporophores, only age and stem quality are used to predict the proportion of decay. For these trees, only class D trees showed significantly different values from the other stem qualities. The predicted percentage of decay volume ranged between 6 to 40\%, depending on stem age and stem quality (Fig. 3a).

\subsection{Net merchantable volume breakdown}

The multinomial regression seems to slightly underestimate the number of stems having one product (Tab. IV). However, the diagonal of this table, corresponding to true predictions, has the greatest values when compared to each line and column, except when 4 products are present. Apart from determining the stems with only pulpwood, the number of products is used as an explanatory variable for the following steps of the breakdown model.

The results of the multinomial regression indicate that the probability of observing many products in a stem increases with increasing stem quality and size (Fig. 4). Moreover, the presence of Phellinus tremulae conks decreases the number of products in the stem. 
Table III. Coefficient values and statistics for predicting the probability of observing decay in a stem as well as its volume when present (all parameter estimates are significant with $5 \%$ error).

\begin{tabular}{|c|c|c|c|}
\hline \multirow{2}{*}{ Coefficients } & \multirow{2}{*}{ Logistical model for predicting the presence of decay } & \multicolumn{2}{|c|}{ Proportion of decay in the stem } \\
\hline & & Without P. tremulae & With P. tremulae \\
\hline$b_{0}($ intercept $)$ & -0.3555 & -0.8990 & -1.5006 \\
\hline$b_{1}\left(\mathrm{age}_{\mathrm{ij}}\right)$ & 0.06521 & 0.01363 & 0.00804 \\
\hline$b_{2}\left(\mathrm{ht}_{\mathrm{ij}}\right)$ & -0.1482 & -0.09176 & \\
\hline$b_{3}\left(\mathrm{reg}_{\mathrm{i}}=4 \mathrm{f} / 4 \mathrm{~h}\right)$ & 0.7038 & 0.3289 & \\
\hline$b_{4}\left(\mathrm{PTCF}_{\mathrm{ij}}\right)$ & 1.2857 & & \\
\hline$b_{5}\left(\right.$ fire $\left._{\mathrm{i}}\right)$ & & 0.2669 & \\
\hline$b_{6, m}$ (tree quality 'A') & & -0.2876 & -0.1871 \\
\hline$b_{6, m}($ tree quality 'B') & & -0.2876 & -0.1871 \\
\hline$b_{6, m}($ tree quality 'C') & & -0.1497 & -0.1871 \\
\hline$b_{6, m}($ tree quality 'D') & & 0 & 0 \\
\hline $\operatorname{cor}^{\mathrm{a}}$ & & 1.5202 & 1.1069 \\
\hline \multicolumn{4}{|l|}{ Statistics } \\
\hline $\mathrm{N}$ & 959 & 686 & 100 \\
\hline RMSE & $\mathrm{n} / \mathrm{a}$ & 0.448 & 0.249 \\
\hline $\mathrm{R}^{2}$ & $\mathrm{n} / \mathrm{a}$ & 0.54 & 0.78 \\
\hline $\mathrm{AIC}^{\mathrm{b}}$ & 4645 & 1015 & 79.2 \\
\hline $\mathrm{BIC}^{\mathrm{c}}$ & 4650 & 1021 & 82.9 \\
\hline-2 Log likelihood & 4641 & 1011 & 75.2 \\
\hline
\end{tabular}

a cor is Duan's correction factor;

${ }^{\mathrm{b}} \mathrm{AIC}$ is Akaike Information Criterion;

c BIC is Schwarz's Bayesian Criterion.
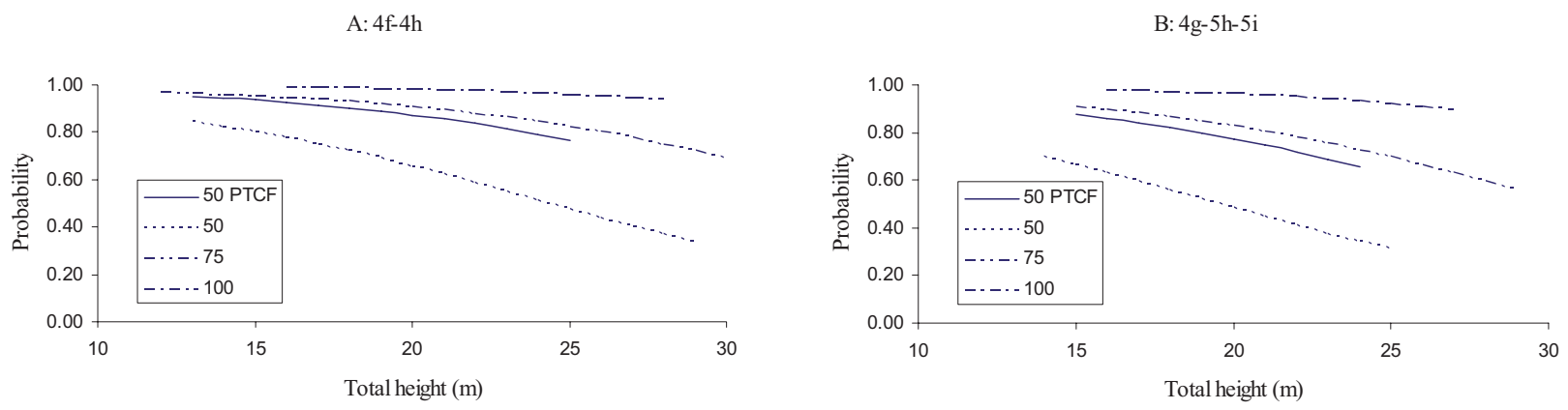

Figure 2. Probability of observing decay in a given stem as a function of tree height, age (50, 75 and 100 years old), presence (PTCF) or absence of Ceratocystis fimbriata and Phellinus tremulae sporophores and ecological region groups (A versus B).

The cutpoints for each binomial regression were calculated by product for each tree quality (Tab. V). The binomial regression for veneer produced the most accurate results with very good specificity and sensibility, followed closely by the results for low-grade veneer (Tab. VI). The model for of low-grade saw $\log$ s resulted in the worst sensibility among the binomial regressions. However, the system for the volume breakdown is normally used in cases where a precise single tree prediction is not required, but where an overall good performance is needed. This was achieved with the present system because small differences were observed between predicted and observed values of presence and absence of the various end-use products.

The probability of observing low-grade saw logs in a stem decreases with increasing stem size because the saw log length increases with increasing stem size (Fig. 5). The inverse trend is observed for the low-grade veneer. The probability of observing large amounts of saw logs increases with decreasing stem quality while the amount of veneer is predicted to increase with increasing stem quality.

The statistics related to the linear regressions for volume prediction are similar to those of the binomial regressions, i.e. the regressions with the highest number of observations have the best fit statistics (Tab. VII). There is however a relatively large variation within the data. Both the low-grade saw log volume and low-grade veneer volume were not affected by the size of the stem. Even without the random effect, all the models predict the correct tendency observed in the data (Fig. 6).

The 10 fold cross-validation shows that the overall system performs well, even though some parts show weaknesses (Tab. VIII). The root mean square error of the PRESS statistic is relatively high, indicating that individual tree variation 
(a)

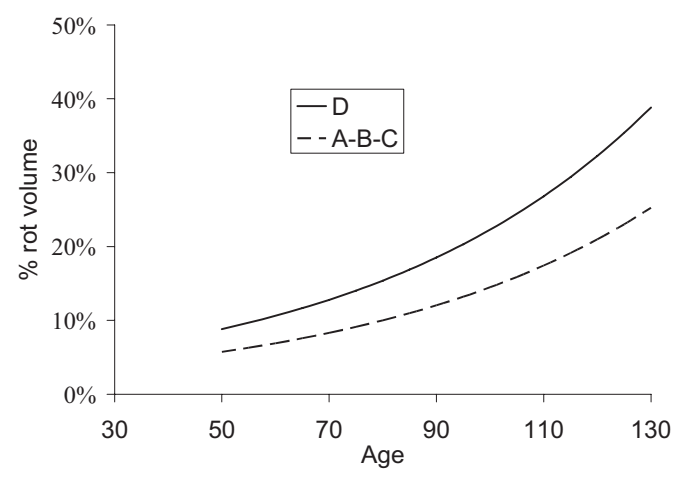

(b)

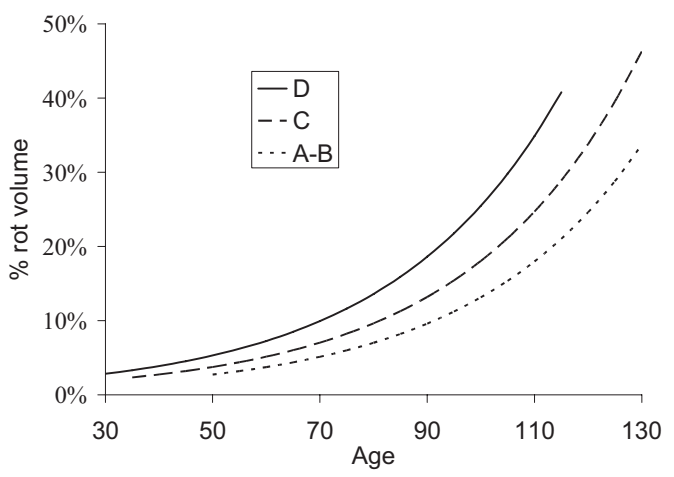

(c)

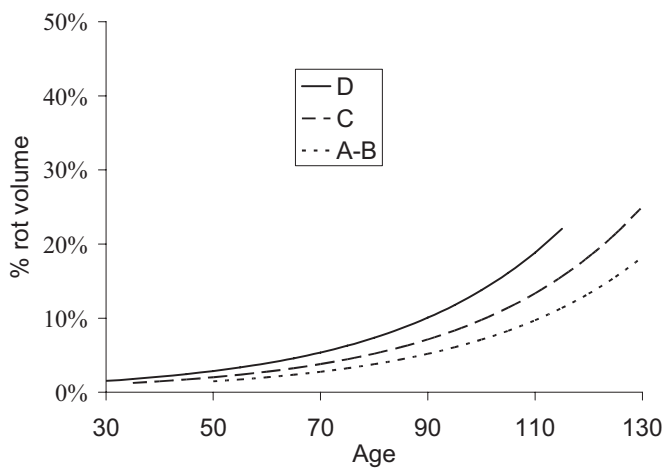

Figure 3. Proportion of decay in a given stem with a height of $20 \mathrm{~m}$ in the $4 \mathrm{f}-4 \mathrm{~h}$ ecological region group as a function of age and stem quality (a: with Phellinus tremulae sporophores, b: without Phellinus and in stand of fire-origin, c: without Phellinus and in stand of cut-origin).

Table IV. Number of products observed in the data and predicted by the multinomial regression per stem.

\begin{tabular}{ccccccc}
\hline & \multicolumn{6}{c}{ Number of predicted products } \\
\cline { 2 - 7 } & \multicolumn{1}{c}{1} & 2 & 3 & 4 & Total \\
\hline \multirow{3}{*}{ Number of observed products } & 1 & 58 & 57 & 0 & 1 & 116 \\
& 2 & 26 & 191 & 30 & 2 & 249 \\
& 3 & 1 & 70 & 60 & 4 & 135 \\
& 4 & 0 & 5 & 24 & 2 & 31 \\
& Total & 85 & 323 & 114 & 9 & 531 \\
\hline
\end{tabular}

is substantial. Biases are however relatively low, with higher relative values being observed for the products with the least volume. When the biases are calculated for each tree quality class, the highest values are observed for the best tree qualities (A and $\mathrm{B}$ ), which also have the least observations. The higher grade products in the lowest stem quality class also show relatively large biases since they are less frequent and thus harder to predict. Although biases can seem relatively large, we have to take into account that a considerable variation is observed for a given product of a certain tree quality.

\section{DISCUSSION}

\subsection{Determination of decay volume}

Two distinct regressions were necessary to determine the volume of decay. First, a logistic regression was calculated to predict the probability that a given tree was affected by decay using all tree observations. Second, a regression equation was calculated to quantify the volume of decay from only stems that were actually affected by rot. The results of these two equations can be used to predict the volume of decay for any trembling aspen tree on the basis of tree characteristics (age, height, quality, presence of fungi indicator), stand origin (fire versus clearcut) and location (ecological region).

The significant effect of ecological regions for both equations suggests that the Gaspésie region, located north-east of the Bas-St-Laurent region, is less affected by decay. This could be related to the presence of forest tent caterpillar (Malacosoma disstria Hbn.) outbreaks that occurred in the BasSt-Laurent region during the 1980's (Lachance et al., 1990). Morawski et al. (1958) considered that these events could lead to a greater amount of decay in aspen by decreasing tree vigour. According to Wall (1971) and Basham (1992), clonal variation, not available in this study, could also contribute to explain such differences. More research is needed to better 


\section{Without Phellinus tremulae conks}

A

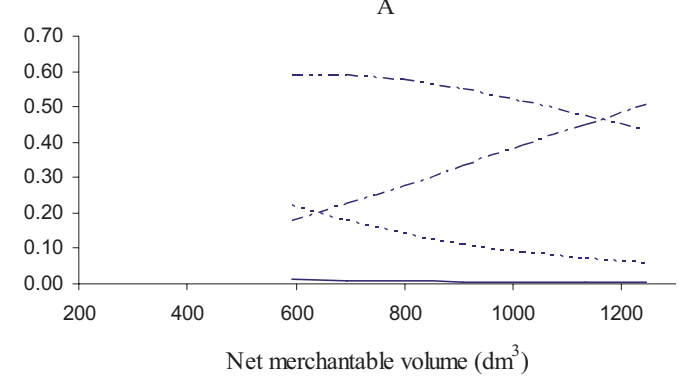

B

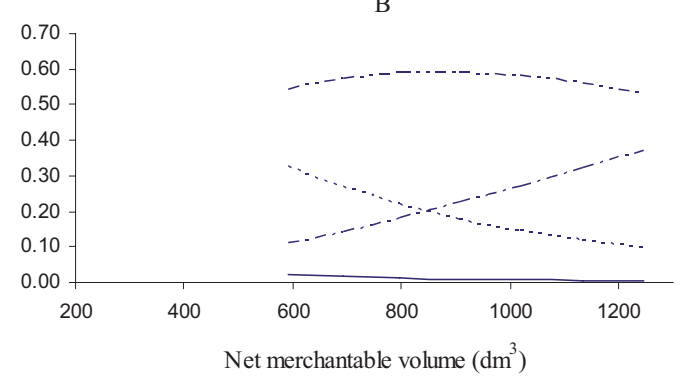

C

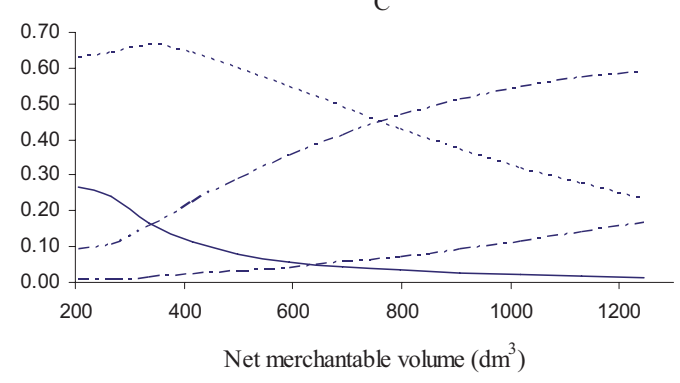

D

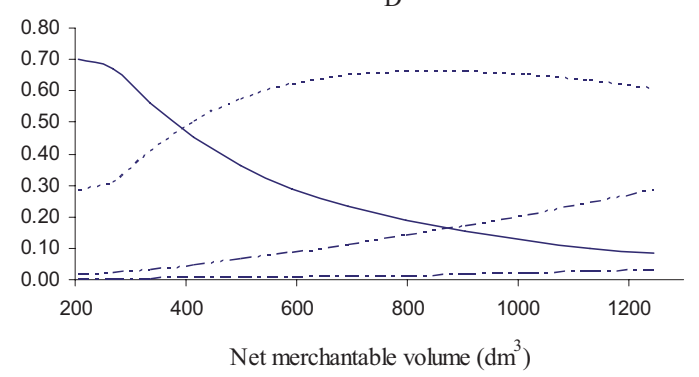

\section{With Phellinus tremulae conks}
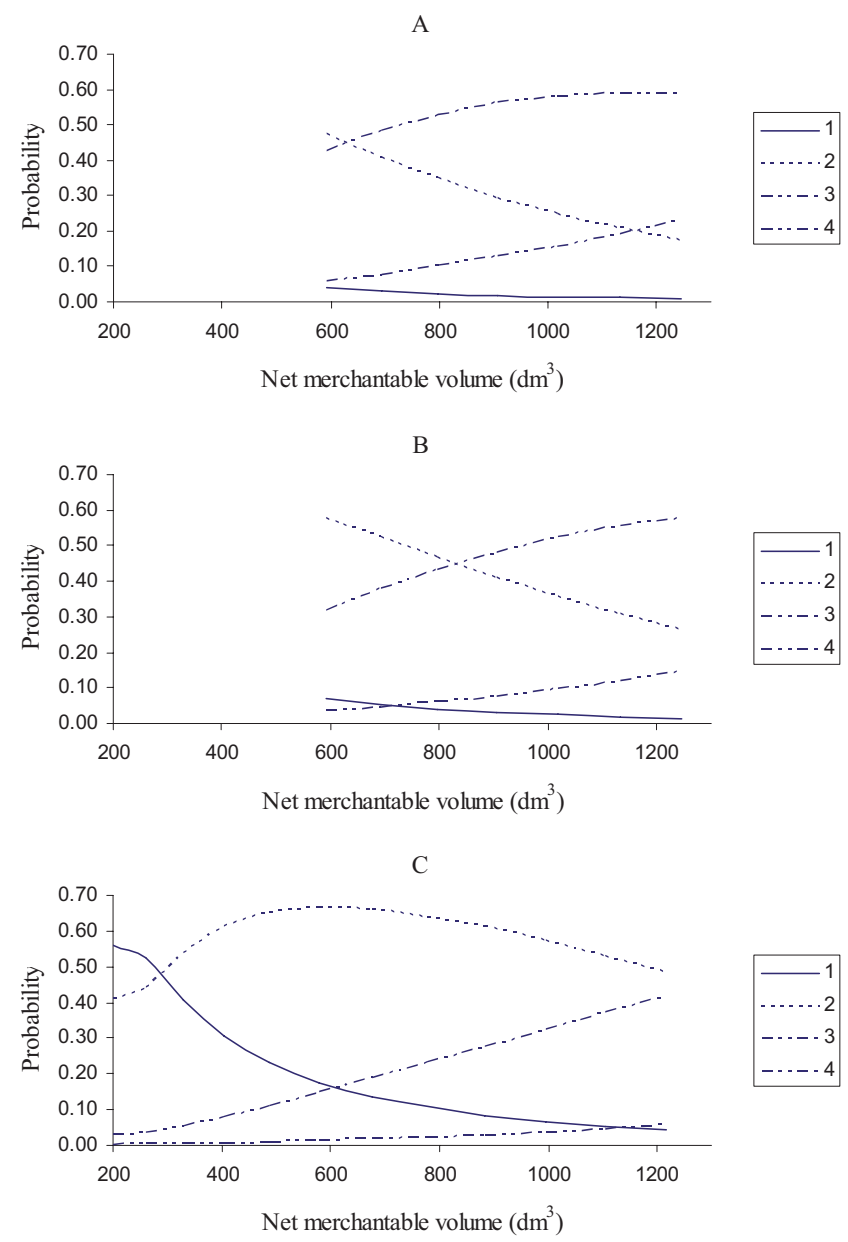

D
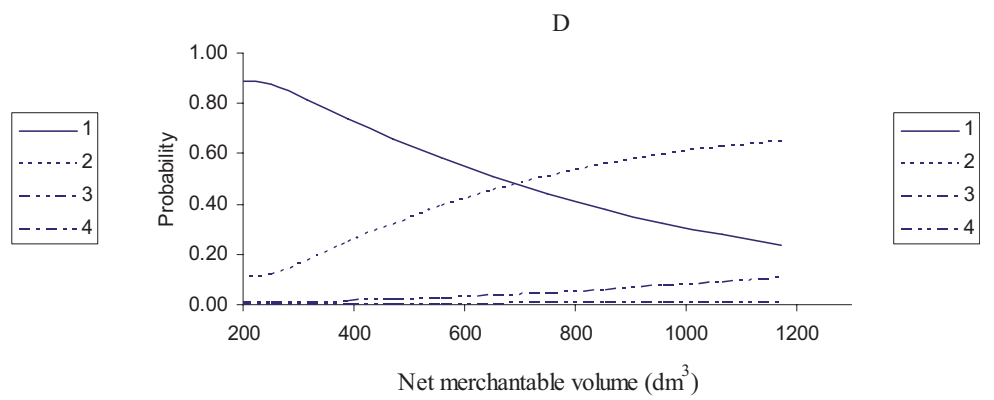

Figure 4. Probability of observing a given number of products in 50 year old stem as a function of stem volume and quality (A, B, C and D), with and without Phellinus tremulae conks.

understand the variation in decay observed between these regions.

As previously reported (Basham, 1958; 1991; 1992; Basham and Morawski, 1964; Hinds and Wengert, 1977; Hiratsuka and Loman, 1984; Morawski et al., 1958; Paul and Etheridge, 1958; Pothier et al., 2004; Riley, 1952 ), the effect of tree age is very important in the prediction of decay volume, where the probability and proportion of decay increases with increasing age. The significant effect of total tree height in the models encompasses both the effect of social status of the stem in the stand and site fertility. This means that a suppressed tree or one growing on less fertile sites will have more chances of having rot. According to the literature reviewed by Thor et al. (2005), the relationship between site and decay remains unclear. In some cases, fertile sites can have more decay whereas the reverse can also be true.

The presence of both Armillaria ostoyae and Hypoxylon mammatum failed to help predict the presence of decay. These fungi are generally associated with tree vigour, but not to the presence of decay (Basham, 1991). They can kill a tree without 
Table V. Values for calculating cutpoints (Eq. (9), \% observed = number of stems with product i/total number of stems).

\begin{tabular}{|c|c|c|c|c|c|c|c|c|}
\hline \multirow{2}{*}{ Tree quality } & \multicolumn{2}{|c|}{ Low-grade saw log } & \multicolumn{2}{|c|}{ Saw $\log$} & \multicolumn{2}{|c|}{ Log grade veneer } & \multicolumn{2}{|c|}{ Veneer } \\
\hline & $\%$ observed & fact $_{\text {cor }}$ & $\%$ observed & fact $_{\text {cor }}$ & $\%$ observed & fact $_{\text {cor }}$ & $\%$ observed & fact $_{\text {cor }}$ \\
\hline$\overline{\mathrm{A}}$ & 0.083 & 0.534 & 0.833 & -0.416 & 0.583 & -0.166 & 0.75 & -0.66 \\
\hline B & 0.071 & 0.098 & 0.869 & -0.188 & 0.595 & -0.09 & 0.357 & 0.126 \\
\hline $\mathrm{C}$ & 0.278 & 0.294 & 0.708 & -0.016 & 0.185 & 0.24 & 0.021 & 0.798 \\
\hline D & 0.117 & 0.116 & 0.383 & -0.166 & 0.071 & 0.358 & 0.019 & 0.802 \\
\hline
\end{tabular}

Table VI. Specificity and sensibility of the logistical regressions for low-grade saw log, saw log, veneer and veneer ( 0 : absence of product; 1: presence of product).

\begin{tabular}{|c|c|c|c|c|c|c|c|}
\hline & & \multicolumn{3}{|c|}{$\begin{array}{c}\text { Predicted } \\
\text { low-grade saw log }\end{array}$} & \multicolumn{3}{|c|}{$\begin{array}{c}\text { Predicted } \\
\text { saw log }\end{array}$} \\
\hline & & 0 & 1 & Total & 0 & 1 & Total \\
\hline \multirow{3}{*}{ Observed } & 0 & 387 & 41 & 427 & 166 & 24 & 190 \\
\hline & 1 & 46 & 57 & 103 & 25 & 316 & 341 \\
\hline & Total & 433 & 98 & 531 & 191 & 340 & 531 \\
\hline & & \multicolumn{3}{|c|}{ Low-grade veneer } & \multicolumn{3}{|c|}{ Veneer } \\
\hline \multirow{3}{*}{ Observed } & 0 & 399 & 12 & 411 & 480 & 3 & 483 \\
\hline & 1 & 13 & 107 & 120 & 2 & 46 & 48 \\
\hline & Total & 412 & 119 & 531 & 482 & 49 & 531 \\
\hline
\end{tabular}

degrading the wood since they mainly affect the cambium. Also, the observation of Hypoxylon mammatum sporophores is difficult, because they are mainly located higher up in the tree as well as on branches with diameters greater than $9 \mathrm{~cm}$. On the other hand, the presence of Phellinus tremulae and Ceratocystis fimbriata sporophores help predict the probability of a stem having decay. These results confirm the earlier reports published by Riley and Bier (1936) who associated the presence of Phellinus tremulae sporophore with the volume of decay in the province of Ontario. In the United States, Anderson and Schipper (1978) related the basal area of trees having at least one carpophore of Phellinus tremulae with the basal area of decay in the trees. The presence of conks (carpophores) has been found to be a good indicator for classification of decayed versus sound trees (LeMay et al., 1994) and a reliable estimator for percent decay (LeMay et al., 1993). As for the presence of Ceratocystis fimbriata sporophores, this fungus can create an entry zone for wood deteriorating pathogens, thus explaining its effect on the prediction of the presence of decay. However, the presence of Ceratocystis fimbriata did not significantly contribute to quantify the amount of decayed wood in the stem (Tab. III) probably because it is not directly responsible for damaging the wood (Myren et al., 1994). The fact that different pathogens produce different probabilities and extents of decay suggests is the presence of a species-specific effect. Differences in the way these different pathogens interact with conifer and deciduous trees have already been reported (Basham, 1991).

According to Table III, trees from fire-origin stands have more rot than those originating from clearcuts. Basham (1992) also observed differences in decay volumes as a function of the origin of aspen stands, even though these differences were not statistically supported. Finally, using quality classes could increase the precision of decay volume prediction in affected aspens.

\subsection{Net merchantable volume breakdown}

A multinomial regression was preferred to a discriminant analysis because it enables the use of categorical independent variables and has less strict underlying assumptions about error distributions (SAS Institute Inc., 2002). The results produced by the regression are less than ideal, but the satisfactory performance of the overall system suggests that this step should be conserved. Indeed, the results of the cumulative logit model are mostly used as an index variable for the next steps instead of being deterministic. In other words, a tree for which the cumulative logit model predicts two end-products might end up having volumes for 3 or 4 end-products, depending on the results of the binomial regressions. This reduces the influence of the results obtained from this cumulative logit model, which is nonetheless important. Preliminary analyses showed that eliminating this step greatly increased the bias of the whole system, but if the results of the cumulative logit model were strictly followed (i.e. a stem with 2 products would only have volumes for 2 end-use products), biases were also observed.

The difficulty in predicting the presence and volume of lowgrade saw logs in the stem arises from the fact that few trees have low-grade saw logs. Furthermore, when present, there is usually only one low-grade saw log per tree. For both small and large trees, the low-grade saw log volume is thus relatively constant and is not related to the visual tree quality classification. Furthermore, larger trees have more chances to have higher grade end-products in the stem. The same observation can be made for the low-grade veneer. The relatively constant volume over all tree sizes indicates that only one of these logs is usually present in a tree. The presence of this product is however more closely related to tree quality than the low-grade saw $\log$. The highest probabilities of saw log occurrence are observed in low quality trees because higher grade products are rarely found in these trees. The highest grade trees have the greatest probability of producing veneer because their logs are not downgraded as often.

The validation procedure results in a high root mean square error of the prediction (RMSEP) that corresponds to a high individual tree variation in the prediction of the volume of each end-use product. The main reason for the high RMSEP is that the system can predict the presence of an end-use product while it is actually absent. However, the objective for the use 
(a)

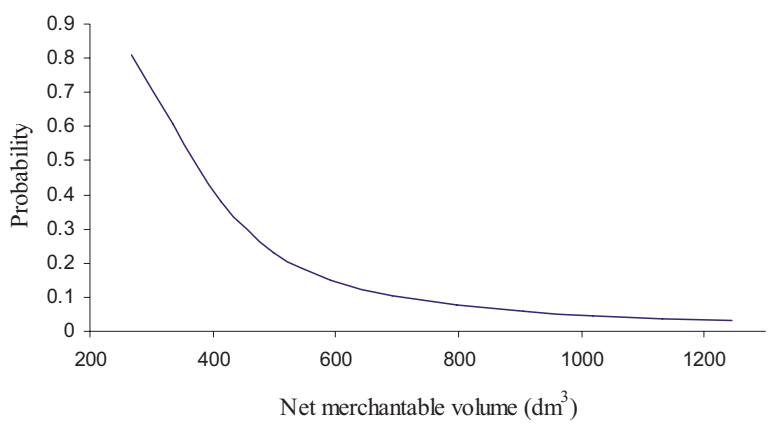

(c)

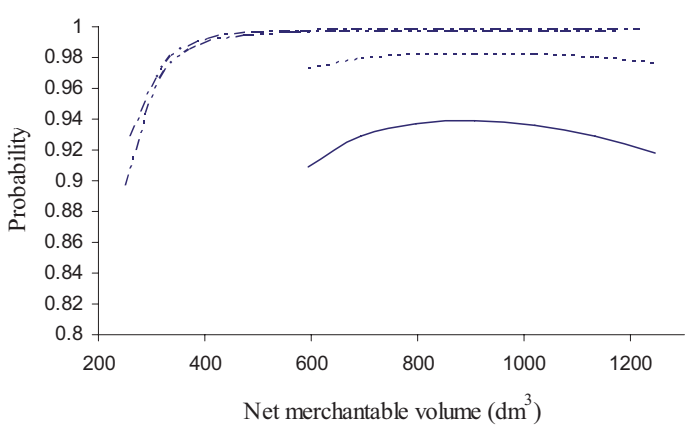

(b)

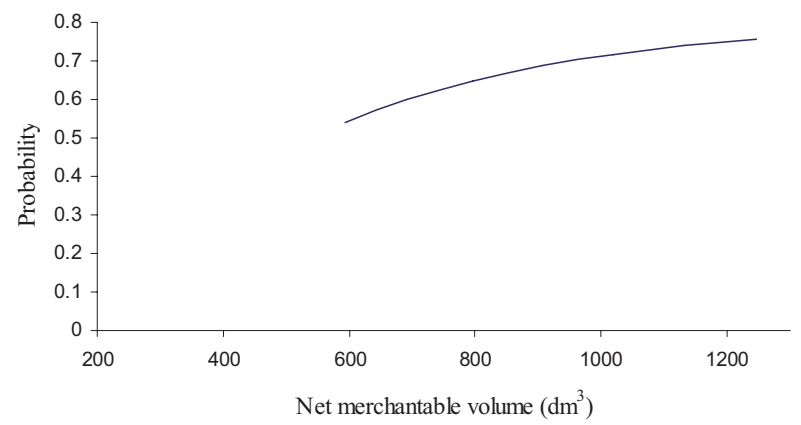

(d)

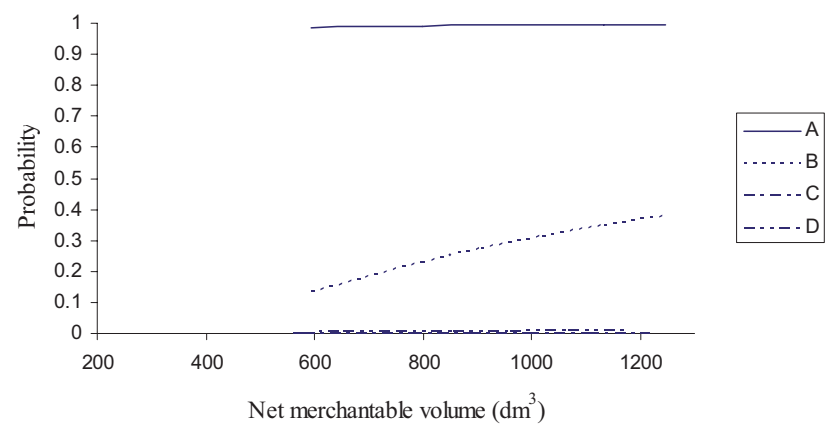

Figure 5. Probability of observing a product for low-grade saw logs (a), saw logs (c, with 3 products in the stem), low-grade veneer (b) and veneer (d, with 3 products in the stem) as a function of net merchantable volume and stem quality (in c and d).

Table VII. Coefficient values and statistics for net merchantable volume breakdown models (pulp: pulpwood; lgsl: low-grade saw log; sl: saw log; lgv: low-grade veneer; v: veneer; all parameter estimates are significant with a $5 \%$ error).

\begin{tabular}{|c|c|c|c|c|c|c|c|c|c|c|}
\hline \multirow{2}{*}{ Coefficients } & \multirow{2}{*}{$\frac{\text { Cumlogit (Eq. (6)) }}{\mathrm{nb}}$} & \multicolumn{4}{|c|}{ Logit (Eq. (8)) } & \multicolumn{5}{|c|}{ Volume $\left(\mathrm{dm}^{3}\right)($ Eq. $(10))$} \\
\hline & & $\begin{array}{c}\text { lgsl } \\
(k=2)\end{array}$ & $\begin{array}{c}\text { sl } \\
(k=3)\end{array}$ & $\begin{array}{c}\operatorname{lgv} \\
(k=4)\end{array}$ & $\begin{array}{c}\mathrm{v} \\
(k=5)\end{array}$ & $\begin{array}{c}\text { pulp } \\
(k=1)\end{array}$ & $\begin{array}{c}\operatorname{lgs} 1 \\
(k=2)\end{array}$ & $\begin{array}{c}\text { sl } \\
(k=3)\end{array}$ & $\begin{array}{c}\operatorname{lgv} \\
(k=4)\end{array}$ & $\begin{array}{c}\mathrm{v} \\
(k=5)\end{array}$ \\
\hline$b_{\mathrm{k}, 01}$ (Intercept) & 0.416 & 1.598 & -2.801 & -10.451 & -37.807 & 2.32 & 1.616 & 1.692 & 1.804 & -1.866 \\
\hline$b_{\mathrm{k}, 03}\left(\right.$ Intercept $\left._{3}\right)$ & 6.341 & & & & & & & & & \\
\hline$b_{\mathrm{k}, 2}\left(\operatorname{Vol}_{\mathrm{net}, 2.5 \mathrm{~m}, \mathrm{ij}}\right)$ & $-1.47 \mathrm{E}-3$ & & & & & $1.12 \mathrm{E}-3$ & $1.46 \mathrm{E}-3$ & & & $5.39 \mathrm{E}-4$ \\
\hline$b_{\mathrm{k}, 21}\left(\mathrm{Vol}_{\mathrm{net}, 2.5 \mathrm{mij}}^{2}\right)$ & & & & & & $-3.16 \mathrm{E}-7$ & $-5.48 \mathrm{E}-7$ & & & \\
\hline$b_{\mathrm{k}, \mathrm{m}}($ tree quality ' $\mathrm{C}$ ') & -1.846 & & 0.406 & & -5.498 & & & 0.0976 & & \\
\hline$b_{\mathrm{k}, \mathrm{m}}($ tree quality 'D') & 0 & & 0 & & 0 & & & 0 & & \\
\hline$b_{\mathrm{k}, 3}\left(\mathrm{age}_{\mathrm{ij}}\right)$ & 0.0151 & & & & & & & & & \\
\hline$b_{\mathrm{k}, 4}\left(\mathrm{hs}_{\mathrm{ij}}\right)$ & -0.119 & -0.328 & 0.518 & 0.197 & 0.274 & & -0.0405 & 0.0304 & & \\
\hline$b_{\mathrm{k}, 5}\left(\mathrm{pt}_{\mathrm{ij}}\right)$ & 1.236 & & & & & & & & & \\
\hline$N$ & 529 & 415 & 399 & 251 & 239 & 415 & 103 & 341 & 119 & 48 \\
\hline RMSE & $\mathrm{n} / \mathrm{a}$ & $\mathrm{n} / \mathrm{a}$ & $\mathrm{n} / \mathrm{a}$ & $\mathrm{n} / \mathrm{a}$ & $\mathrm{n} / \mathrm{a}$ & 0.156 & 0.137 & 0.188 & 0.17 & 0.1 \\
\hline $\mathrm{R}^{2}$ & $\mathrm{n} / \mathrm{a}$ & $\mathrm{n} / \mathrm{a}$ & $\mathrm{n} / \mathrm{a}$ & $\mathrm{n} / \mathrm{a}$ & $\mathrm{n} / \mathrm{a}$ & 0.66 & 0.38 & 0.54 & 0.46 & 0.8 \\
\hline
\end{tabular}


Table VIII. Validation results by end-use product for all tree qualities and for each tree quality (pulp: pulpwood; lgsl: low-grade saw log; sl: saw log; lgv: low-grade veneer; v: veneer).

\begin{tabular}{|c|c|c|c|c|c|c|c|}
\hline & & \multicolumn{2}{|c|}{ Observed } & \multicolumn{3}{|c|}{ Predicted } & \multirow[b]{2}{*}{$\begin{array}{c}\text { Relative bias } \\
(\%)\end{array}$} \\
\hline & & $\begin{array}{c}\text { Average } \\
\left(\mathrm{dm}^{3}\right)\end{array}$ & $\begin{array}{c}\text { Standard deviation } \\
\left(\mathrm{dm}^{3}\right)\end{array}$ & $\begin{array}{c}\text { RMSEP } \\
\left(\mathrm{dm}^{3}\right)\end{array}$ & $\begin{array}{c}\text { Relative RMSEP } \\
(\%)\end{array}$ & $\begin{array}{c}\text { Bias } \\
\left(\mathrm{dm}^{3}\right)\end{array}$ & \\
\hline \multirow{5}{*}{ For all tree qualities } & Pulp & 339 & 197 & 191 & 56 & 32 & 9 \\
\hline & $\operatorname{lgs} 1$ & 16 & 37 & 38 & 238 & -4 & -25 \\
\hline & sl & 173 & 186 & 164 & 95 & -4 & -2 \\
\hline & $\lg v$ & 64 & 141 & 135 & 211 & -11 & -17 \\
\hline & $\mathrm{v}$ & 29 & 104 & 87 & 300 & -10 & -34 \\
\hline \multirow{5}{*}{$\mathrm{A}(n=12)$} & Pulp & 554 & 293 & 315 & 57 & -57 & -10 \\
\hline & $\operatorname{lgs} l$ & 6 & 21 & 21 & 350 & -6 & -100 \\
\hline & sl & 270 & 160 & 220 & 81 & -21 & -8 \\
\hline & $\lg v$ & 239 & 286 & 275 & 115 & 28 & 12 \\
\hline & $\mathrm{v}$ & 377 & 299 & 311 & 82 & -38 & -10 \\
\hline \multirow{5}{*}{ B $(n=84)$} & Pulp & 389 & 200 & 290 & 75 & 112 & 29 \\
\hline & $\operatorname{lgs} 1$ & 6 & 25 & 33 & 550 & -1 & -17 \\
\hline & sl & 288 & 200 & 240 & 83 & -42 & -15 \\
\hline & $\operatorname{lgv}$ & 191 & 217 & 241 & 126 & -26 & -14 \\
\hline & $\mathrm{v}$ & 101 & 157 & 163 & 161 & -33 & -33 \\
\hline \multirow{5}{*}{$\mathrm{C}(n=281)$} & Pulp & 290 & 157 & 165 & 57 & 27 & 9 \\
\hline & $\operatorname{lgs} 1$ & 24 & 42 & 43 & 179 & -3 & -13 \\
\hline & sl & 173 & 169 & 146 & 84 & -9 & -5 \\
\hline & $\lg v$ & 45 & 104 & 105 & 233 & -8 & -18 \\
\hline & $\mathrm{v}$ & 5 & 38 & 38 & 760 & -5 & -100 \\
\hline \multirow{5}{*}{$\mathrm{D}(n=154)$} & Pulp & 383 & 223 & 150 & 39 & 4 & 1 \\
\hline & $\operatorname{lgs} 1$ & 9 & 28 & 31 & 344 & -5 & -56 \\
\hline & sl & 101 & 174 & 138 & 137 & 27 & 27 \\
\hline & $\lg v$ & 16 & 63 & 69 & 431 & -12 & -75 \\
\hline & $\mathrm{v}$ & 4 & 32 & 33 & 825 & -4 & -100 \\
\hline
\end{tabular}

of this prediction system must not be overlooked. High precision at the individual stem level is not necessary, because the prediction system is used on a management unit scale. The important point is thus to minimize the overall bias. Furthermore, tree sampling was stratified as a function of tree quality, i.e. the good quality trees (grades ' $A$ ' and ' $B$ ') were rarer and were thus not sampled as extensively as the low quality trees (grades ' $C$ ' and ' $D$ '). The overall bias irrespective of tree quality is low for all the products and thus meets one of the objectives of this study. More work would however be necessary to increase the prediction at the stem level, if the needs arise.

Regional differences in volume breakdown were observed in the data, but can be entirely explained by the use of the saw log length. The Gaspésie region, which lies to the north of the sampling region and has greater changes in altitude, has fewer high end-products in a stem. For a given dbh, the stems in this region are shorter, and thus have short saw log heights. This reduces the number of products as well as the probability of observing higher end-products. The presence of the Phellinus tremulae conks also influences the volume breakdown by influencing the number of products that are found in a given stem. The end-product system actually used by the Quebec Ministry of Natural Resources should thus be expanded to in- clude such variables as saw log length and the presence of Phellinus tremulae conks if better predictions are wanted.

\section{CONCLUSION}

This study led to the calibration of models that predict the presence and amount of decay in trembling aspen stems. These models account for regional differences by the inclusion of ecological regions, stand characteristics and tree variables. As for the net merchantable volume breakdown, a new method is proposed that works well for the intended purposes. It shows that important variables such as age, presence of Phellinus tremulae conks, and saw log length which are not presently included in the method used by the Quebec Ministry of Natural Resources should be used to increase the performance of

Figure 6. Residuals as a function of predicted values as well as the observed and predicted (with and without random effects) volumes as a function of total net merchantable volume of the stem ((a) pulpwood volume; (b) low-grade saw log volume; (c) saw log volume; (d) lowgrade veneer volume; (e) veneer volume). 


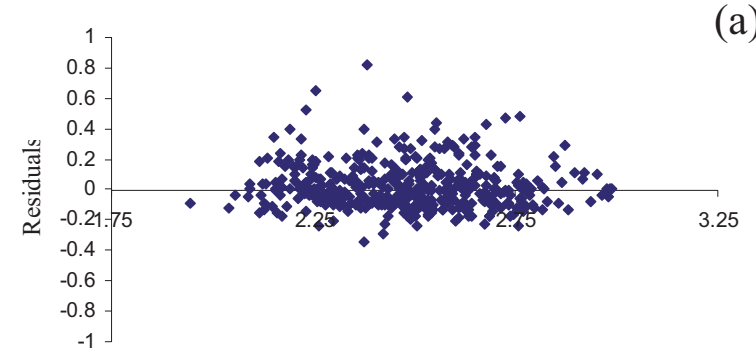

Predicted $\log _{10}$ (Pulpwood volume)

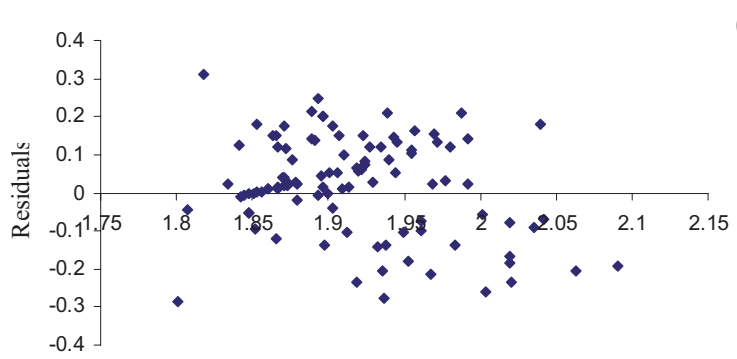

Predicted $\log _{10}$ (Low grade saw log volume)

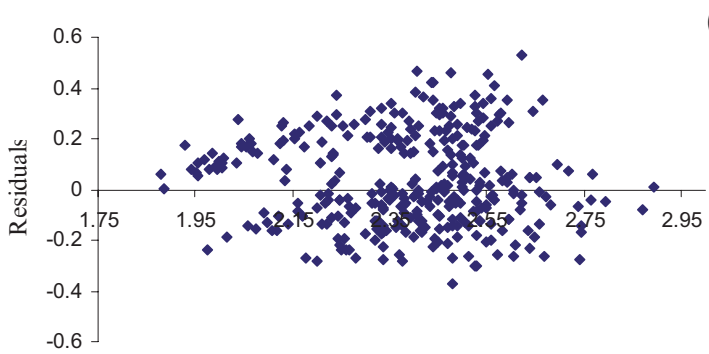

Predicted $\log _{10}$ (Saw log volume)

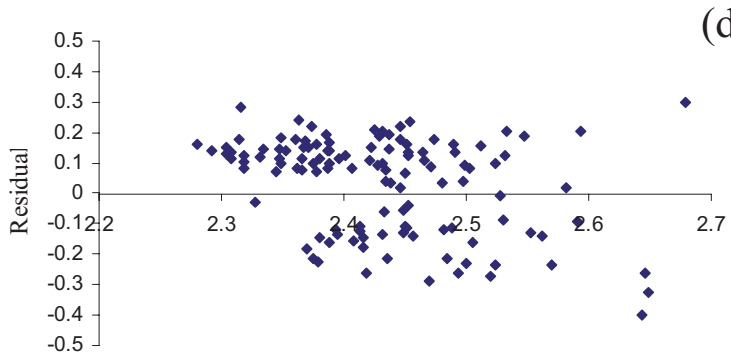

Predicted $\log _{10}$ (Low grade veneer volume)

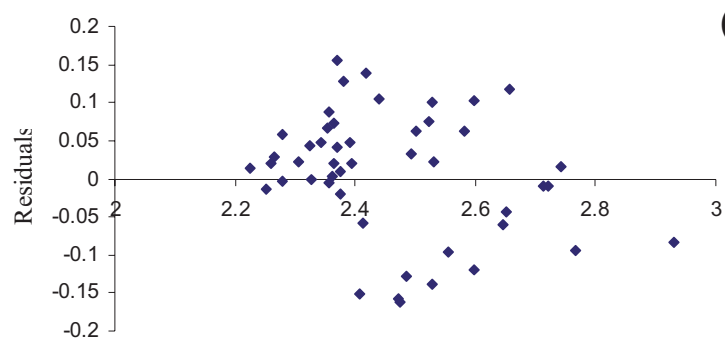

Predicted $\log _{10}$ (Veneer volume)

(a)

(b)

d)

(e)
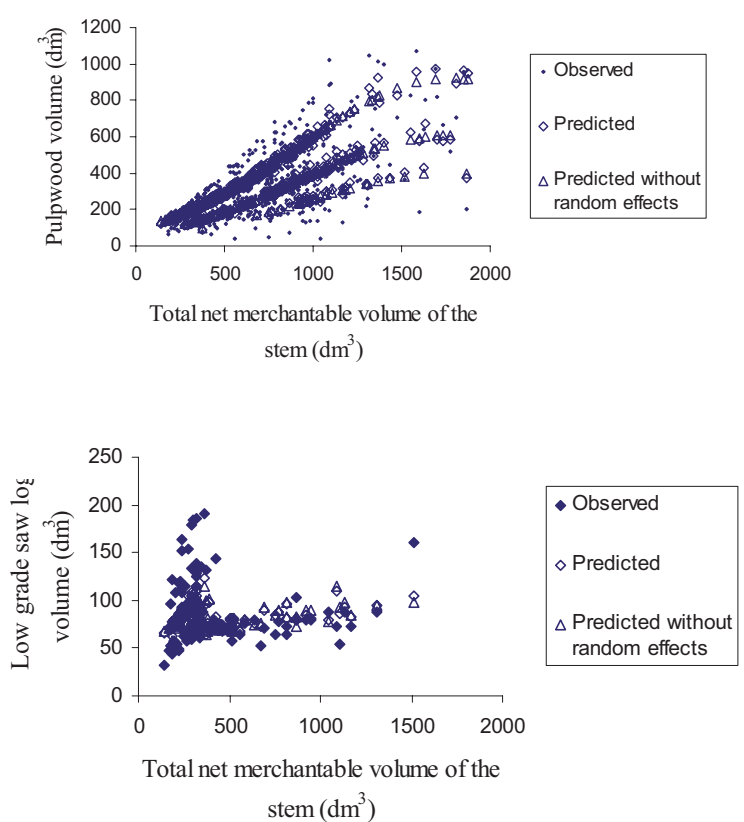

(c)
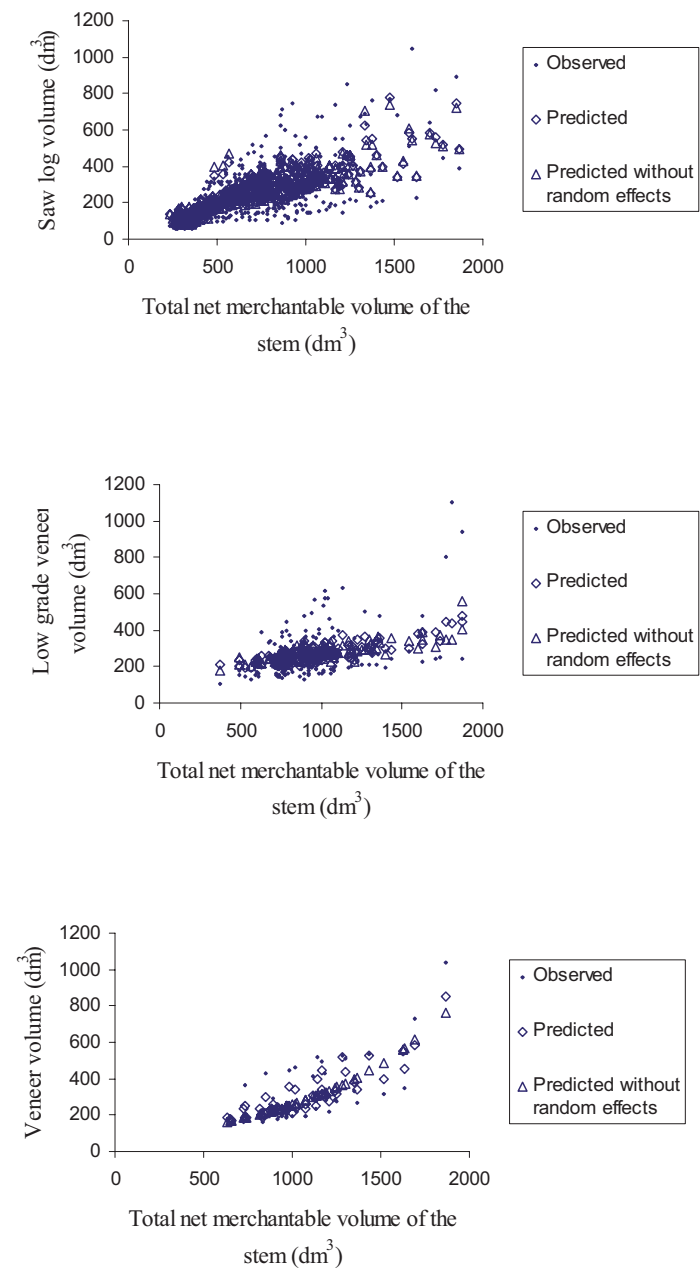
the system. Further research would however be necessary to increase the accuracy of the predictions at the individual stem level. These results, which have already been included in forest management decisions, should enable a better management of trembling aspen stands.

Acknowledgements: Financial support was provided by the Quebec Ministry of Natural Resources. The authors thank the following persons for their support and technical contributions: Bruno Boulet, Jean-Pierre Saucier, Gaétan Daigle, Philippe Racine, Isabelle Auger, Anie Brûlé. Reviews by Mathieu Fortin, Edwin Swift, Girvan Harrison and two anonymous reviewers were greatly appreciated.

\section{REFERENCES}

Allison P.D., 1999. Logistic regression using the SAS system: theory and applications. Cary, NC, SAS Institute Inc.

Anderson R.L., 1964. Hypoxylon canker impact on aspen. Phytopathology 54: 253-257.

Anderson R.L. and Schipper A.L. Jr., 1978. A system for predicting the amount of Phellinus (Fomes) igniarius rot in trembling aspen stands. North Central forest experiment station, USDA Forest Service, Research Note NC-232.

Basham J.T., 1958. Decay of trembling aspen. Can. J. Bot. 36: 491-505.

Basham J.T., 1991. Stem decay in living trees in Ontario's forests: a users' compendium and guide. For. Can., Ont. Region, Sault Ste. Marie, Ont. Inf. Rep. 0-X-408.

Basham J.T., 1992. Trembling aspen quality in northern Ontario - various aspects of decay and stain studies and their management implications. For. Can., Ont. Region, Sault Ste. Marie, Ont. Inf. Rep. $0-\mathrm{X}-421$

Basham J.T. and Morawski. Z.J.R., 1964. Cull studies. The defects and associated Basidiomycete fungi in the heartwood of living trees in the forests of Ontario. Can. Dep. For., For. Entomol. Pathol. Br., Ottawa, Ont. Publ. 1072.

Belli K.L., Matney T.G., Hodges J.D., Deen R.T., and Goelz J.C.G., 1993. Tree grade prediction for Mississippi bottomland hardwoods using discriminant analysis. South. J. Appl. For. 17: 120-123.

Blouin D., Patry A., Lessard G., and Ménard B., 2001. Optimisation de la classification des tiges sur pied par type écologique. Rapport final de mise en valeur des ressources du milieu forestier. CERFO.

Collett D., 2003. Modelling binary data, 2nd ed. Chapman and Hall/CRC, New York.

Davidson R.W., Atkins R.C., Fry R.D., Racey G.D., and Weingartner D.H., 1988. A silvicultural guide for the poplar working group in Ontario. Ont. Min. Nat. Resour., Toronto, Ont. Sci. And Technol. Series, Vol. 5.

Duan N., 1983. Smearing estimate: a non parametric retransformation method. J. Am. Stat. Assoc. 78: 605-610.

Good P.I., 2001. Resampling methods: a practical guide to data analysis, 2nd ed. Boston, MA Birkhäuser.

Hilpp G.K. and Pelkki M.H., 2003. Log grade prediction for standing yellow-poplar trees in eastern kentucky. South. J. Appl. For. 27: 6165.

Hinds T.E. and Wengert E.M., 1977. Growth and decay losses in Colorado aspen. Rocky Mountain Forest and Range Experiment Station USDA, Forest Service, Research Paper RM-193.
Hiratsuka Y. and Loman A.A., 1984. Decay of aspen and balsam poplar in Alberta. Environ. Can., Can. For. Serv., North. For. Res. Cent., Edmonton, Alberta. Inf. Rep. NOR-X-262.

Knoke T., 2003. Predicting red heartwood formation in beech trees (Fagus sylvatica L.). Ecol. Model. 169: 295-312.

Lachance D., 1984. Armillaria root rot. For. Can. Sainte-Foy, Québec, Canada. Information report CRFL 14.

Lachance D., Monnier C., Bérubé J.-P., and Paquet R., 1990. Forest insects and diseases in the Gaspé/Lower St. Lawrence region 19361987. For. Can. Sainte-Foy, Québec, Canada. Information report LAU-X-93.

LeMay V.M., Kozak A., and Marshall P.L., 1993. Using limited dependent variable estimators for estimating percent decay. Can. J. For. Res. 23: 266-274.

LeMay V.M., Tait D.E., and Van Der Kamp B.J., 1994. Classification of cedar, aspen, and true fir trees as decayed versus sound. Can. J. For. Res. 24: 2068-2077.

Littell R.C, Milliken G.A., Stroup W.W., and Wolfinger R.D., 1996. SAS system for mixed models. Cary, NC, SAS Institute Inc.

Ministère des Ressources naturelles, 2001. Méthode de mesurage des bois. Instructions. Avril 2001. Mesurage informatisé, Direction de l'assistance technique, Ministère des Ressources naturelles, Gouvernement du Québec.

Morawski Z.J.R., Basham J.T., and Turner K.B., 1958. Cull studies. A survey of a pathological condition in the forests of Ontario. Ont. Dep. Lands For., Div. Timber, Toronto, Ont. Rep. No. 25.

Morris D.M. and Parker W.H., 1992. Variable-quality form in mature jack pine stands: Quantification and relationship with environmental factors. Can. J. For. Res. 22: 279-289.

Myren D.T., Laflamme G., Singh P., Magasi L.P., and Lachance D., 1994. Tree Diseases of Eastern Canada, Natural Resources Canada, Canadian Forest Service, Ottawa, Ont.

Ordre des ingénieurs forestiers du Québec, 2003. Dictionnaire de la foresterie, Édition spéciale, Marc Côté (Ed.).

Paul G. and Etheridge D.E., 1958. Decay of aspen (Populus tremuloides Michx.) and balsam poplar (P. balsamifera L.) in the Lesser Slave Lake in Alberta. Alberta Dep.Land.For., For. Surv. Div., Edmonton, Alberta, and Can. Dep. Agric., For. Biol. Div., Calgary, Alberta.

Patry A., 2004. Analyse de la croissance et de la carie des essences résineuses. Régions du Bas-Saint-Laurent et de la Gaspésie. Direction des inventaires forestiers. Forêt Québec. Ministère des Ressources naturelles, de la Faune et des Parcs. Gouvernement du Québec.

Perron J.-Y., 1985. Tarif de cubage général, volume marchand brut. Ministère de l'Énergie et des Ressources, Gouvernement du Québec.

Perron J.-Y. and Morin P., 2001. Normes d'inventaire forestier : Placettes-échantillons permanentes, Édition 2001. Direction des inventaires forestiers, Forêt Québec, Ministère des Ressources naturelles, Gouvernement du Québec.

Pothier D., Raulier F., and Riopel M., 2004. Ageing and decline of trembling aspen stands in Quebec. Can. J. For. Res. 34: 1251-1258.

Pothier D. and Savard F., 1998. Actualisation des tables de production pour les principales espèces forestières du Québec. Gouvernement du Québec, Ministère des Ressources naturelles, RN98-3054.

Press S.J. and Wilson S., 1978. Choosing between logistic regression and discriminant analysis. J. Am. Stat. Assoc. 73: 699-705.

Prestemon J.P., 1998. Estimating tree grades for Southern Appalachian natural forest stands. For. Sci. 44: 73-86. 
Quebec Provincial Government, 2007. Loi sur les forêts. L.R.Q. chapitre F-4.1 [electronic copy available at http:// www2.publicationsduquebec.gouv.qc.ca/dynamicSearch/telecharge. php?type $=2 \&$ file $\left.=/ F \_4 \_1 / F 4 \_1 . h t m\right]$.

Riley C.G., 1952. Studies in forest pathology. IX. Fomes igniarius decay of poplar. Can. J. Bot. 30: 710-734.

Riley C.G. and Bier J.E., 1936. Extent of decay in poplar as indicated by the presence of sporophores of the fungus Fomes igniarius Linn. For. Chron. 12: 249-253.

Robitaille A. and Saucier J.-P., 1998. Paysages régionaux du Québec méridional. Les publications du Québec, Sainte-Foy, Québec.

SAS Institute Inc., 2002. SAS OnlineDoc ${ }^{\circledR} 9$. http://v9doc.sas.com/sasdoc/ [Consulted on June 25th 2005].

SAS Institute Inc., 2006. The GLIMMIX Procedure, June 2006. SAS Institute, Cary, NC. [electronic copy available at http://www.sas.com/statistics/doc.html].

Saucier J.-P., Bergeron J.-F., Grondin P., and Robitaille A., 1998. Les régions écologiques du Québec méridional ( $3^{\mathrm{e}}$ version) : un des éléments du système hiérarchique de classification écologique du territoire mis au point par le ministère des Ressources naturelles du Québec. Supplément de l'Aubelle, No. 124.
Seifert T., 2007. Simulating the extent of decay caused by Heterobasidion annosum s.1. in stems of Norway spruce. For. Eco. Manage. 248: 95106.

Thor M., Ståhl G., and Stenlid J., 2005. Modelling root rot incidence in Sweden using tree, site and stand variables. Scan. J. For. Res. 20: $165-176$.

Vanclay J.K., 1994. Modelling forest growth and yield: applications to mixed tropical forests. Wallingford, Oxon, UK, CAB International.

Wall R.E., 1971. Variation in decay in aspen stands as affected by their clonal growth pattern, Can. J. For. Res. 1: 141-146.

Walters J.M., Hinds T.E., Johnson D.W., and Beatty J., 1982. Effects of partial cutting on diseases, mortality, and regeneration of Rocky Mountain aspen stands. Rocky Mountain Forest and Range Experiment Station, USDA Forest Service, Res. Pap. RM-240.

Yaussy D.A., Brisbin R.L., and Humphreys M.J., 1988. Predicting volumes and numbers of logs by grade from hardwood cruise data. Northeastern Forest Experiment Station, USDA Forest Service, Res. Pap. NE-613.

Zycha H., 1962. Hymenomycetes. In: Sorauer P., Appel O., Blunck H., Rademacher B., Richter H. (Eds.), Handbuch der Pflanzenkrankheiten. Parey-Verlag, Berlin, pp. 550-575. 